\title{
REFLECTIONS
}

\section{Linking Ruth to Her Past}

Renate G. Justin, MD

\begin{abstract}
A family physician shares the story of her 3-decade-long relationship with a patient and the strong ties that they formed. Although she was taught to keep emotionally distant from her patients in order to maintain the best therapeutic milieu, this relationship enriched the author's experience as a physician and ministered to her patient's needs.
\end{abstract}

Ann Fam Med 2004;2:512-513. DOI: 10.1370/afm.232.

$\mathrm{T}$ Ooward the end of my career as a family physician, I worked for a health maintenance organization. In this medical care system, I could not be with my patients during times of crisis. If they were acutely ill and hospitalized, a hospitalist attended them We did not share in the joys of life, birth, or recovery from a serious illness, nor did we share in tragedies, death, or disability. My relationship with my patients was friendly and respectful, but not intimate.

At the beginning of my practice as a family physician, 50 years ago, my relationship with my patients was quite different. I cared for several generations of the same family. I looked after some patients from birth to death. Some encounters with patients lasted $10 \mathrm{~min}$ utes, other were much longer; some were preponderantly objective and scientific, during others our souls touched. This subtle interplay of objective and subjective responses required an ability to listen, to divine what the specific meeting of the doctor and patient demanded. The relationships between my patients and myself varied as the colors on the artist's palate.

My relationship with Ruth evolved over 3 decades. Ruth and I first met when I attended her birth and then when her grandmother brought her to the office for delayed immunizations. Ruth's mother died in the early 1960s of breast cancer when Ruth was not quite 2 years old. Ruth's paternal grandmother moved in with her son to look after her little granddaughter. The

\section{CORRESPONDING AUTHOR}

Renate G. Justin, MD

900 Wild Cherry Lane

Fort Collins, CO 80521

rjustin@greyrock.org well-child checkup was uneventful ${ }_{i}$ Ruth was a cuddly baby with the same big brown eyes that had graced her mother's face. I inquired about the grandmother's wellbeing, and she said, "Ruth is keeping me alive, without her I wouldn't be here."

I saw Ruth for her school physical examination when she was 5 years old. It was hard to believe the cute baby had reached school age. She was fine, pretty with long dark hair; she looked like her mom. She also was smart, and I predicted accurately that she would do well in school. She no longer suffered acutely from the deprivation caused by her mother's death; she had bonded well to her grandmother. I stopped worrying about who would nurture this little girl and shepherd her through her teenage years. I sent her off with a hug and "enjoy school."

The next visit was for a sports physical. We were becoming better acquainted, and I knew that Ruth trusted me when she asked about birth control, a subject her grandmother found difficult to discuss. My own children were close to Ruth in age, and I felt protective and motherly toward her, especially as her grandmother was aging.

When I filled out college forms about her past and present health history, Ruth and I began to talk about her genetic predisposition to breast cancer. I took care of her mother and 3 aunts who died of this disease. Ruth thought her maternal grandmother, whom I did not know, also died at a young age of breast cancer. I taught Ruth self-breast examination, and we discussed the need for frequent office visits to allow me to check her breasts. We also weighed the option of bilateral mastectomies, but Ruth rejected this choice, saying, "I want to have children and want to be able nurse them." I wished that I owned a genetic wand that I could wave over her.

Ruth's father remarried and moved to another town. Her biyearly office visits did not raise concern. Ruth graduated from college, and her grandmother died during the same week. We saw each other frequently during the following months and talked about Ruth's great loss. I was now the female adult in her life who had known her longer than any one, and the only one who had known her family. We mourned not only Ruth's grandmother, but also her mother, whom I remembered 
as possessing quietude and the surety that comes with inner peace. Ruth was much like her. During this time of sadness, we had long talks and frequent telephone calls. I respected Ruth. She managed on her own after her grandmother's death and in due time became joyful and optimistic. When she visited the office, she greeted each of us with a warm smile and "Hi, Freda, how is your Mom?" or "Rita, does your little one walk yet?"

Ruth and her fiancé came in for premarital serologic tests. Tom, whom she met in college, was an accountant. I liked him. We discussed birth control, but Ruth and Tom desired to have children soon. I sent a card on their first wedding anniversary. Not long after, when Ruth called, my receptionist interrupted me. She had detected panic in Ruth's voice. I picked up the telephone and knew what had happened before Ruth told me. I asked her to come to the office without delay. She was crying when I entered the examination room, and I used a tissue to dry her tears and then gave her the box. My palpation confirmed Ruth's findings - there was a mass in her left breast, small, but hard. I felt no nodes but was as apprehensive as Ruth. I had a clear sense of déjà vu. How long ago was it that I had felt a similar mass in Ruth's mother's breast? We talked, picked a surgeon, and got an appointment in the afternoon.

I arrived at the hospital early the morning of surgery and found Tom sitting on Ruth's bed holding her in his embrace. They both had been crying. I fought to keep my own tears from spilling, yet I resisted the impulse to be reassuring when I could not find cause for optimism. I was no longer an objective observer of this tragedy, I had become an engaged participant.

Ruth had a radical mastectomy, and after surgery I spent many hours with her and Tom explaining the most recent protocol for breast cancer and how it would influence fertility, longevity, and quality of life. We also grieved together. After months of intravenous chemotherapy, hospitalizations for staphylococcal infections in her left arm, and radiation, Ruth's menses resumed, and she and Tom were soon anticipating the birth of their first child. They were ecstatic. I felt like a happy grandparent, but worried and anxious. I knew the statistics only too well.

When little Frank arrived, we were relieved that he was a healthy baby boy. Ruth and Tom named him after me and his other grandmothers. I saw them often. Tom always came to the office with Frank and Ruth. Frank was only 2 years old when we discovered that Ruth's cancer had recurred. Ruth was angry that she had to die young — she was only in her late 20s — that she wasted the months of treatment, nausea, and misery, and as she said, "it did no good."

We now were friends, and I no longer wore a white coat when I visited Ruth at home. Her house was located on a lake, and we sat on its shore together watching the fish jump and the ducks teach their young how to swim. The concern of the ducks for their ducklings caused Ruth to weep. "Who will teach my duckling how to walk, to swim?" She made me promise over and over that I would not abandon Tom and Frank after she died. We embraced as I left, both of us aware that our time together was short. As I drove home, I allowed myself to sob. My friend was dying, and there was no way to delay the inevitable.

During the funeral I held Frank in my arms; he wanted to play in the grass, run around. I reflected on my first friendly, but distant "hello" to Ruth as a tiny infant, and my tearful "good-bye" to my close friend. I saw Tom and Frank regularly until Frank was ready to start school. By that time, Tom had found a partner, and their beautiful new home was at a distance from where Ruth was buried.

Would Ruth's life have been different today, now that geneticists have identified the familial breast cancer gene that can deplete the women in a family? I do not think so. I believe that Ruth would have rejected genetic testing; she wanted to remain hopeful.

Knowing Ruth over decades, in joy and despair, inevitably formed strong ties between us. My relationship with her included being a physician, a substitute parent, a grandparent, and at the end, a friend. I did not hesitate to fill these roles. By allowing my feelings to be expressed, I enriched my own experience as a physician; at the same time, I ministered to Ruth's, my patient's, needs.

As a physician I was taught to keep emotionally distant from my patients so I could maintain the best therapeutic milieu. I "have been trained in medicine to believe that subjectivity is the enemy of science-even truth." ${ }^{11}$ Ruth and I could not maintain distance, especially at the end of her life. At that moment friendship, closeness rather than distance, was likely more therapeutic because it recognized our common humanity.

It was the experience of being present in different roles in Ruth's as well as in her family's life for many years that made being her family physician humbling and rewarding.

To read or post commentaries in response to this article, see it online at http://www.annfammed.org/cgi/content/full/2/5/512.

Key words: Physician-patient relations; continuity of patient care; primary health care; family practice

Submitted July 22, 2003; submitted, revised, November 6, 2003; accepted January 13,2004

\section{Reference}

1. Cassel EJ. The Healers Art. Philadelphia, Penn: JB Lippincott Co; 1976:105. 